\title{
INTER-ANNUAL RAINFALL VARIABILITY AND DROUGHTS OCCURRENCE DURING SOWING AND MID-SEASON RICE FARMING CALENDAR IN THE FOREST BELT OF NIGERIA
}

\author{
Atedhor, G. O. ${ }^{1}$ and Ayeni, O. A. ${ }^{2}$ \\ ${ }^{1}$ Dept. of Geography \& Regional Planning, University of Benin, Benin City, Nigeria \\ godwin.atedhor@uniben.edu,08136446117 \\ ${ }^{2}$ Dept. of Geography, University of Lagos, Lagos, Nigeria aoayeni@unilag.edu.ng, 08035894730 \\ (Received: 24th March, 2017; Accepted: 30th June, 2017)
}

\begin{abstract}
This study examined the trends of rainfall and the intensity of drought during sowing season and mid-season of rice farming calendar in the rainforest belt of Nigeria using data spanning 52 years (1961-2012) for five synoptic weather stations. The trends were investigated using simple linear regression and second order polynomial, while the significance of the trends was evaluated using Pearson's Product Moment Correlation. The drought intensities during the two seasons were computed as percentage derivations from the mean. Rainfall during the sowing season witnessed upward trends in Ondo, Port Harcourt, Benin and Calabar at annual rates of $0.450 \mathrm{~mm}$, $1.005 \mathrm{~mm}, 3.581 \mathrm{~mm}$ and $2.144 \mathrm{~mm}$ respectively with statistical significance in Benin $(0.398, \mathrm{p}<0.01)$ and Calabar $(0.295, \mathrm{p}<0.05)$ while Warri witnessed insignificant decline at an annual rate of $-0.525 \mathrm{~mm}$. Rainfall in the midseason witnessed insignificant increase in Warri, Ondo, Port Harcourt and Calabar at annual rates of $0.096 \mathrm{~mm}$, $0.118 \mathrm{~mm}, 0.172 \mathrm{~mm}$ and $0.016 \mathrm{~mm}$ respectively. Rain-days declined insignificantly in all the stations during the sowing season with the exception of Port Harcourt which witnessed significant decrease $(-0.268, \mathrm{p}<0.05)$ while mid-season rain-days declined in all the stations but only significantly in Warri $(-0.301, \mathrm{p}<0.05)$ and Ondo ($0.366, \mathrm{p}<0.01)$. The droughts intensities varied mainly between slight and moderate intensities during the two seasons with pockets of severe and disastrous intensities in Port Harcourt and Warri. It was concluded that rainfall trends was upward in all the stations with the exception of Warri and Benin with declining trends during the sowing season and mid-season respectively while rain-days were decreasing in the two seasons coupled with droughts mainly of slight and moderate intensities. The study suggested an early rainfall forecast and timely irrigation for optimal rice production in the region.
\end{abstract}

Key words: Rainfall, rain-days, drought, rice, rainforest belt, Nigeria

\section{INTRODUCTION}

Climate variability remains one of the most critical determinants of inter-annual crop output, including high yield and technology farming regions (Kang et al., 2009; Craufurd \& Wheeler, 2009; Zhao \& Fitzgerald, 2013). Meanwhile, changes in temperature and precipitation as a result of global climate change could have severe implications on hydrologic processes, water resources accessibility, irrigation water use, and thus upsetting agricultural production and output (Abeysingha et al., 2016). Water availability has been identified as one of the threats to crop production and food security (Kang et al., 2009). Relatively, only a four percent of the total arable land in sub-Saharan Africa is irrigated (ACPC, 2011). This implies that agriculture is predominantly rain-fed which makes the sector particularly vulnerable to the vagaries of climatic variability and change.
Climate change is expected to threaten agriculture and established farming systems (Gornall et al., 2010). While temperature is the most critical climatic determinant of the length of the growing in the temperate environment (Ayoade, 2002), in the tropical region where Nigeria is located, rainfall is more cardinal. Although the surface location of the Inter-Tropical Discontinuity (ITD) is a relevant model for explaining rainfall pattern over the Nigeria landscape (Ilesanmi, 1971; Olaniran, 2002; Odekunle, 2009), other mechanisms include Biogeophysical Feedback Mechanism (BFM), El Nino Southern Oscillation (ENSO) and Sea Surface Temperature Anomalies (Adebayo, 1999; Olaniran, 2002; Umar, 2010; Ati, 2010).

Improved understanding of the influence of climate parameters on rice quality offers information for innovative breeding schemes to develop selections of rice modified to a changing 
global environment (Zhao and Fitzgerald, 2013). Although several studies on crop-weather relations have employed crop-simulation models (Wart et al., 2013; Sultan et al., 2014; Lobell and Asseng, 2017), crop simulation models based on General Circulation Models (GCMs) have high potentials at large spatial scales with limitations at regional and local levels (Koide et al., 2013). Thus, an understanding of the influence of inter-annual climate variations on crop yields in different regions remains elusive (Ray et al., 2015).

Rice is fast becoming a key food in many parts of sub-Saharan Africa due to due to increasing population growth (Kihoro et al., 2013). Nigeria's mean rice import was 5,680,600 thousand metric tons per annum between 1980 and 2013, while mean production was $8,587,268$ thousand metric tons during the same period (Onu et al., 2015). This implies that local rice production in the country is far below demand. Although the forest belt of Nigeria is particularly suitable for the cultivation of tree and tuber crops owing to the relatively high annual rainfall amount, the cultivation of grains such as rice also thrive in the region. Analysis of climatic parameters vis-á-vis rice production are largely savannah belts biased (Ayoola et al., 2011; Ayinde et al., 2013). This study, therefore, examines inter-annual rainfall variability in the forest belt of Nigeria with a view to providing insight into prevailing environmental factors during the early and mid-season of rice farming calendar.

\section{Study Area}

The rainforest belt of Nigeria (Fig. 1) is warm and humid with mean temperature of about $27^{\circ} \mathrm{C}$ and annual rainfall amount usually up to $2000 \mathrm{~mm}$. The wet season lasts from March to October (Odekunle, 2004). It falls within Köppen's Af climatic classification type. The vegetation is characteristically dense as a result of the high annual rainfall amount. Agriculture is primarily rain-fed and in addition to the prevalence of tree and food crops, pockets of rice farming occur in the region. The renewed national drive for selfsufficiency food production with particular emphasis on rice production is currently intensifying the rice farming throughout the country.

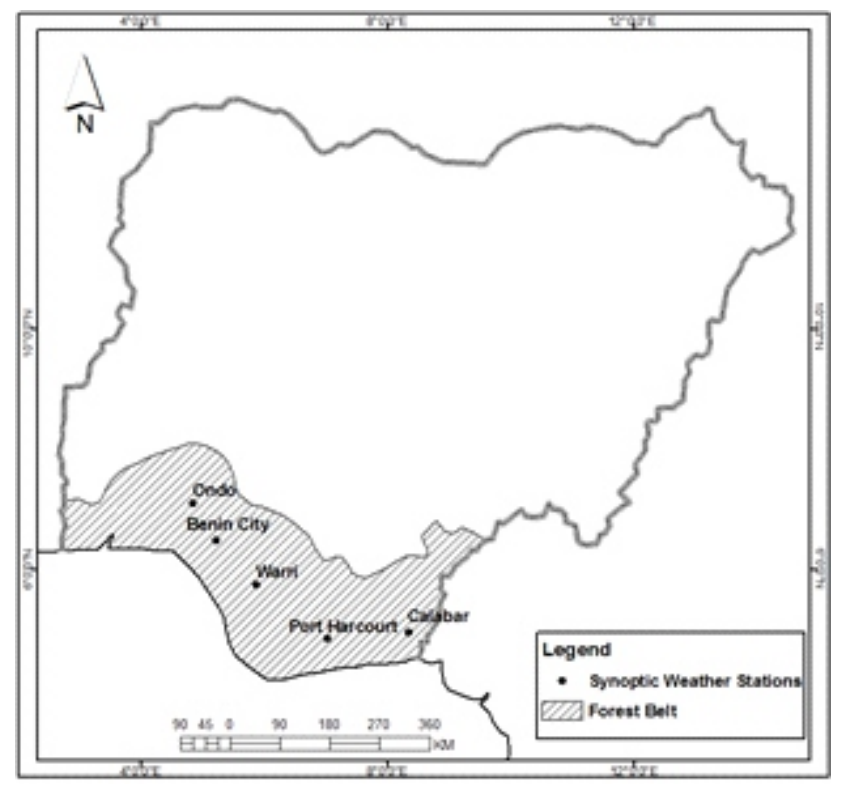

Fig. 1: The forest belt of Nigeria and the synoptic stations for the study

\section{MATERIALS AND METHODS}

Rainfall, temperature and solar radiation have been ranked as the most critical climatic factors in crop production (Nyang'au et al., 2014). However, low temperature and solar radiation are not limiting factors to crop production in Nigeria as it is in the temperate region because of its location in the tropics where the sun is at its zenith virtually throughout the year. It is inter-annual rainfall variability both in terms of rainfall amount and its 
distribution (rain-days) that limits crop growth and yield inter-annually. Consequently, stationbased monthly rainfall and rain-days data for five synoptic weather stations (Warri, Ondo, Port Harcourt, Benin and Calabar) in the forest belt of Nigeria were analyzed in this study. The data which were collected from the archive of the Nigerian Meteorological Agency spanned a period of 52 years (1961-2012). The data were partitioned into the sowing season (April-May) and (June-July) in line with prevailing rice farming calendar in the region (Crop Calendar of Nigeria, n.d.). The trends of each of the climatic parameters during the two seasons were examined using simple linear regression and second order polynomial while the significance of the trends was analyzed using Pearson's Product Moment Correlation. Years constituted the independent variable while each of the climatic elements represented the dependent variable. The annual trends of mid-season rainfall and rain-days less sowing season rainfall and rain-days respectively were used to evaluate the sustained rainfall, and by extension, soil moisture during the mid-season. The annual intensities of droughts during the sowing and mid-seasons were computed as percentage derivation from the mean. The drought intensities were categorized as: 11-25 (slight), 26- 45 (moderate), 46-60 (severe) and above 60 (disastrous).

\section{RESULTS AND DISCUSSION}

The annual trends of rainfall during the sowing season and mid-season of the rice farming calendar in the forest belt of Nigeria are presented in Fig. 2 (a-e). While negative annual trend of rainfall in the sowing season was witnessed in Warri during the period under consideration, Ondo, Port Harcourt, Benin and Calabar experienced positive annual trend of rainfall. In Warri, sowing season rainfall decreased annually at the rate of $-0.525 \mathrm{~mm}$ but increased in Ondo, Port Harcourt, Benin and Calabar at the rates of 0.450 $\mathrm{mm}, 1.005 \mathrm{~mm}, 3.581 \mathrm{~mm}$, and $2.144 \mathrm{~mm}$ respectively (Table 1). However, during the midseason, only Benin witnessed negative annual trend of rainfall. Mid-season rainfall decreased in Benin at an annual rate of $0.876 \mathrm{~mm}$ while it increased in Warri, Ondo, Port Harcourt and Calabar at annual rates of $1.200 \mathrm{~mm}, 1.029 \mathrm{~mm}$, $2.072 \mathrm{~mm}$, and $1.696 \mathrm{~mm}$ respectively. The increasing trends of sowing season rainfall were only significant in Benin $(\mathrm{r}=0.398, \mathrm{P}<0.01)$ and Calabar $(r=0.295, P<0.05)$. The annual trends of mid-season rainfall in all the selected stations were not significantly different each other at $\mathrm{p}<0.01$.

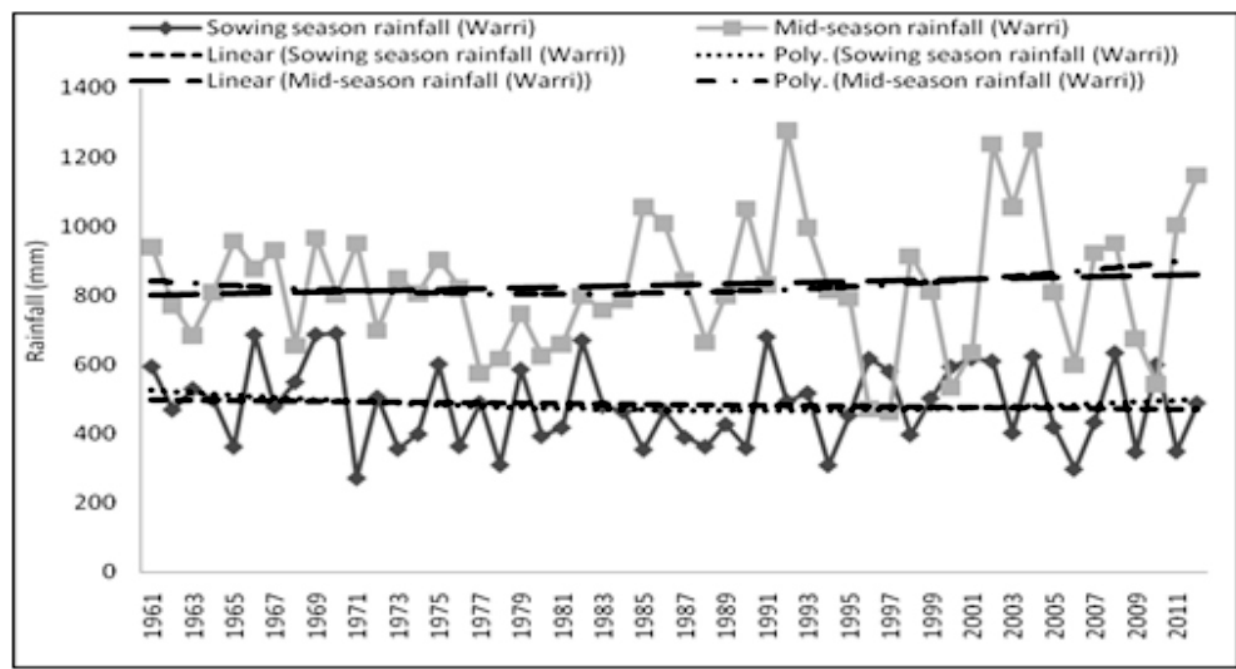

Fig. 2a: Annual trends of sowing season and mid-season rainfall in Warri 


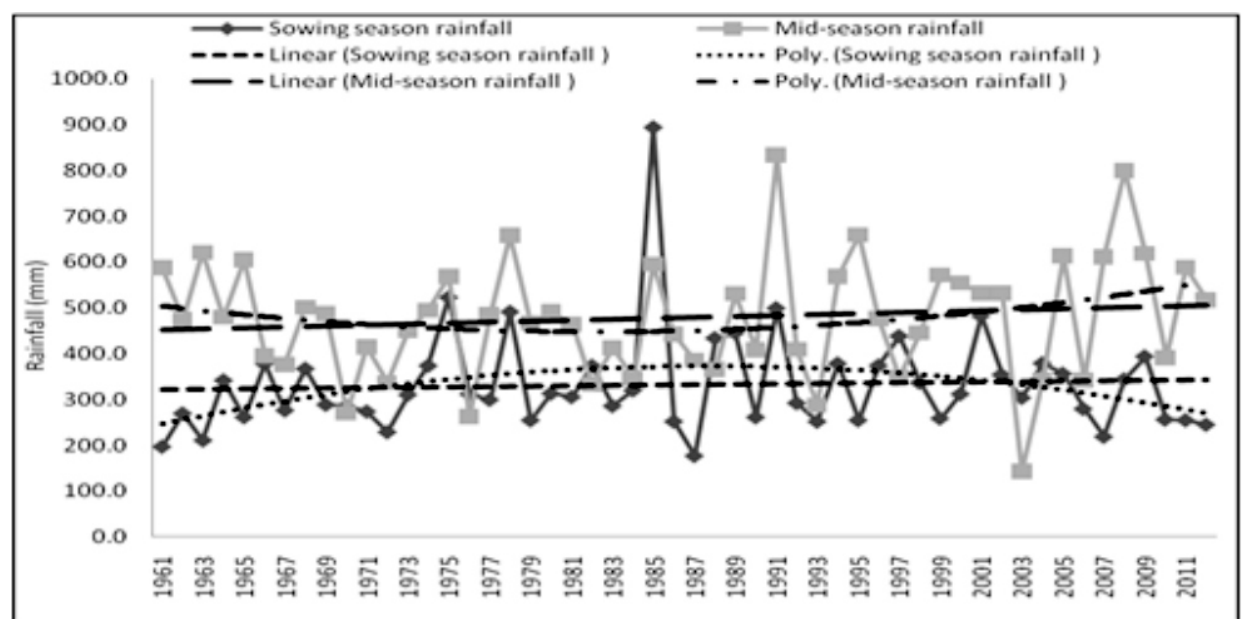

Fig. 2b: Annual trends of rainfall during sowing season and mid-season in Ondo

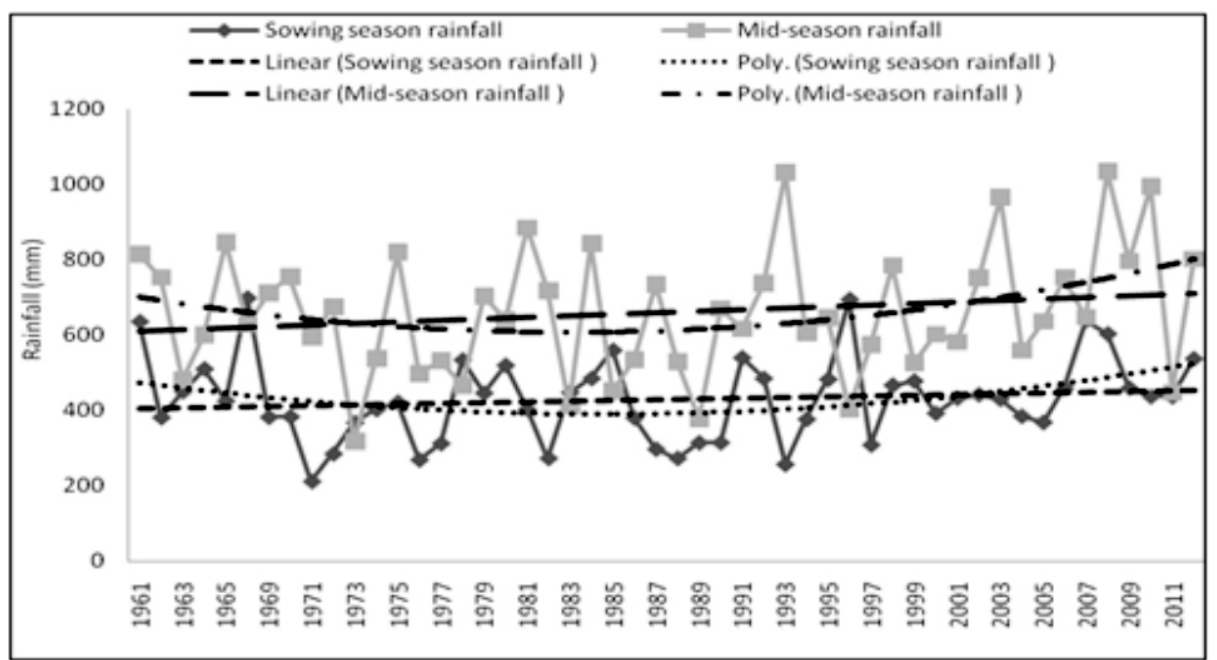

Fig. 2c: Annual trends of rainfall during the sowing season and mid-season in Port Harcourt

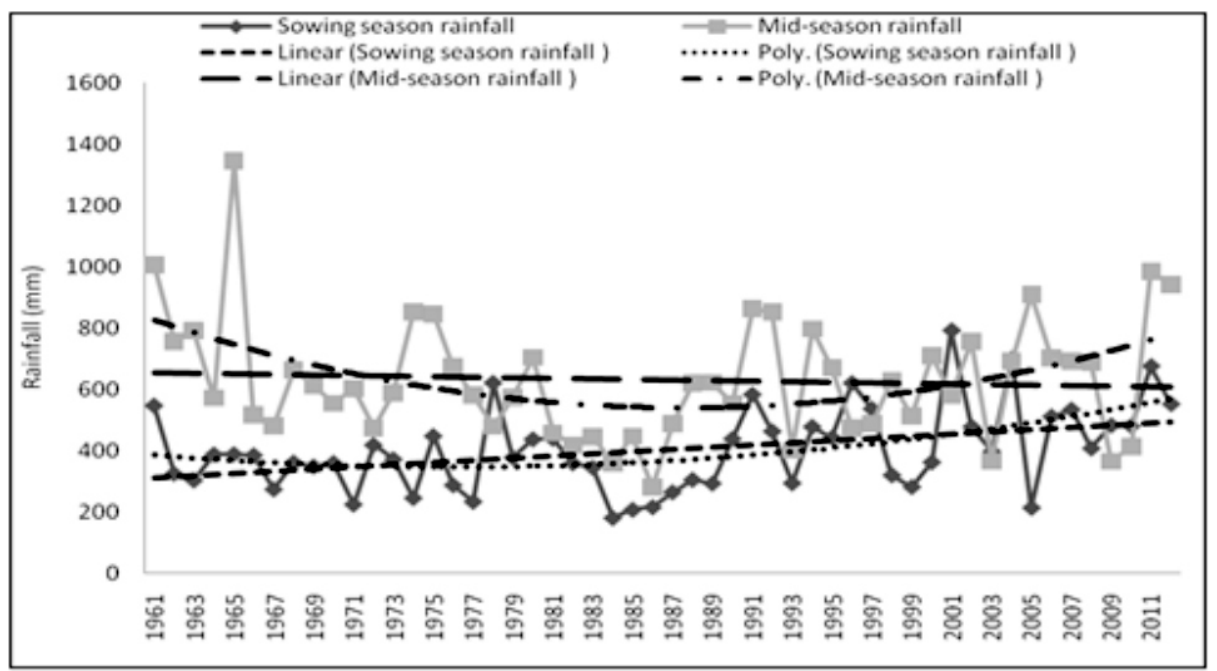

Fig. 2d: Annual trends of rainfall during the sowing and mid-season in Benin 


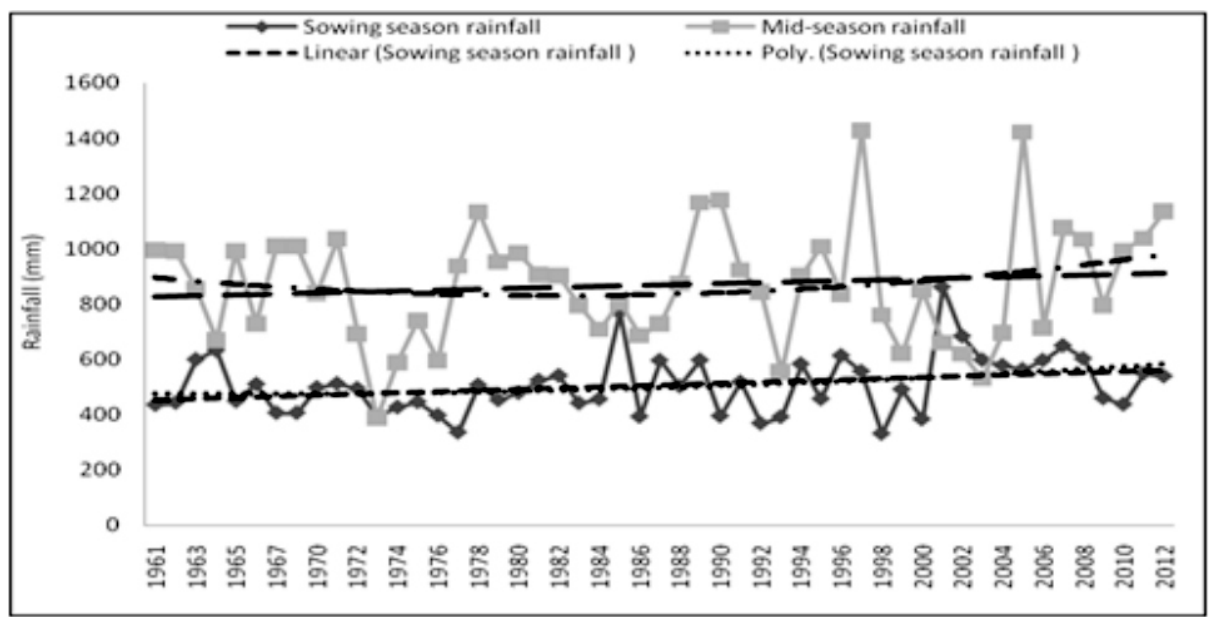

Fig. 2e: Annual trends of rainfall during the sowing and mid-season in Calabar

Table 1: Regression equations and correlations coefficients of the trends of sowing season and midseason rainfall

\begin{tabular}{|c|c|c|}
\hline Synoptic weather station & Regression equations (Sowing season) & Correlation coefficients \\
\hline Warri1 & $y=497.9-0.525 x$ & -0.069 \\
\hline Ondo1 & $\mathrm{y}=320.6+0.450 \mathrm{x}$ & 0.061 \\
\hline Port Harcourt1 & $y=404.2+1.005 x$ & 0.115 \\
\hline Benin1 & $y=308.4+3.581 x$ & $0.398 * *$ \\
\hline Calabar1 & $y=451.2+2.144 x$ & $0.295^{*}$ \\
\hline Warri2 & $\mathrm{y}=797.9+1.200 \mathrm{x}$ & 0.096 \\
\hline Ondo2 & $\mathrm{y}=451.1+1.029 \mathrm{x}$ & 0.118 \\
\hline Port Harcourt2 & $y=607.6+2.072 x$ & 0.172 \\
\hline Benin2 & $y=654.5-0.877 x$ & -0.066 \\
\hline Calabar2 & $y=824.9+1.696 x$ & 0.016 \\
\hline Warri3 & $y=339.7+0.402 x$ & 0.035 \\
\hline Ondo3 & $y=119.9+0.661 x$ & 0.08 \\
\hline Port Harcourt3 & $y=176.6+1.432 x$ & 0.127 \\
\hline Benin3 & $y=318.2-2.896 x$ & -0.238 \\
\hline Calabar3 & $y=326.0+0.777 x$ & 0.059 \\
\hline Warri4 & $y=30.50+0.007 x$ & -0.093 \\
\hline Ondo4 & $y=12.77-0.005 x$ & -0.033 \\
\hline Port Harcourt4 & $y=27.28-0.022 x$ & $-.268^{*}$ \\
\hline Benin4 & $\mathrm{y}=41.05-0.060 \mathrm{x}$ & -0.019 \\
\hline Calabar4 & $y=34.81-0.004 x$ & -0.103 \\
\hline Warri5 & $y=47.47-0.114 x$ & $-.301^{*}$ \\
\hline Ondo5 & $y=19.79-0.081 x$ & $-.366^{* *}$ \\
\hline Port Harcourt5 & $\mathrm{y}=34.78+0.110 \mathrm{x}$ & -0.08 \\
\hline Benin5 & $y=25.84-0.005 x$ & -0.133 \\
\hline Calabar5 & $y=45.57-0.004 x$ & -0.174 \\
\hline Warri6 & $y=339.7+0.402 x$ & 0.035 \\
\hline Ondo6 & $y=119.9+0.661 x$ & 0.08 \\
\hline Port Harcourt6 & $y=176.6+1.432 x$ & 0.127 \\
\hline Benin6 & $\mathrm{y}=318.2-2.896 \mathrm{x}$ & -0.238 \\
\hline Calabar6 & $y=326.0+0.777 x$ & 0.059 \\
\hline
\end{tabular}

*. Correlation is significant at the 0.05 level (2-tailed).

**. Correlation is significant at the 0.01 level (2-tailed).

where, 1,2,3,4,5 and 6 represent sowing season rainfall, mid-season rainfall, mid-season rainfall less sowing season rainfall, sowing season raindays, mid-season rain-day, mid-season rain-days less sowing season rain-days respectively 
The trends of mid-season rainfall less sowing season rainfall are presented in Fig. 3 (a-e). The linear trends of mid-season rainfall less sowing season rainfall showed upward trend in Warri, Ondo, Port Harcourt and Calabar at annual rates of $0.402 \mathrm{~mm}, 0.661 \mathrm{~mm}, 1.432 \mathrm{~mm}$ and $0.777 \mathrm{~mm}$ respectively during the 1961-2012 period, while the trend in Benin depicted downward trend at an annual rate of $-2.896 \mathrm{~mm}$ during the period under review. The correlation coefficients of midseason rainfall less sowing season rainfall for Warri, Ondo, Port Harcourt, Benin and Calabar were $0.035,0.08,0.127,-0.238$ and 0.059 respectively which are however not significant at 0.05 confidence level. The trends of mid-season rainfall less sowing season rainfall in the selected stations based on the second order polynomial exhibited low degree of curvilinear pattern in Warri and Port Harcourt with the trends in Ondo, Benin and Calabar appearing to be clearly less linear. Accordingly, Ondo displayed a downward trend from 1961 to the lowest at around 1983-87 which was followed by increasing trend thereafter. The trend in Benin based on the second order polynomial showed that it experienced declining trend during the 1961-2000 with signs of recovery thereafter, while similarly but less pronounced, Calabar witnessed downward trend with slight sign of upturn.

The downward trend of mid-season rainfall less sowing season rainfall in Benin clearly showed low rainfall during the mid-season which could jeopardize the moisture requirement during the post sowing season. The linear trend of midseason rainfall less sowing season rainfall in Benin as well as the downward trends before the upsurge displayed by the second order polynomial for Ondo, Benin and Calabar, were clear signals of the need for climatic forecasts and monitoring as well as irrigation for optimal rice growth and yield since soil moisture is germane at germination and tender stage of the growth of rice.

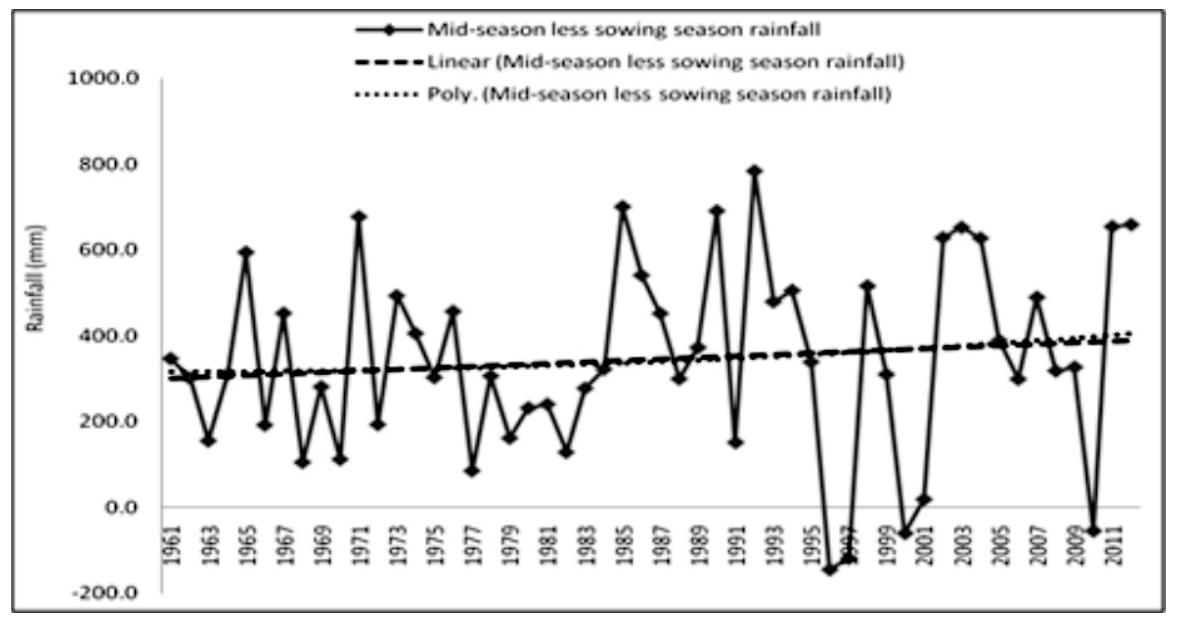

Fig. 3a: Annual trend of mid-season rainfall less sowing season rainfall in Warri 


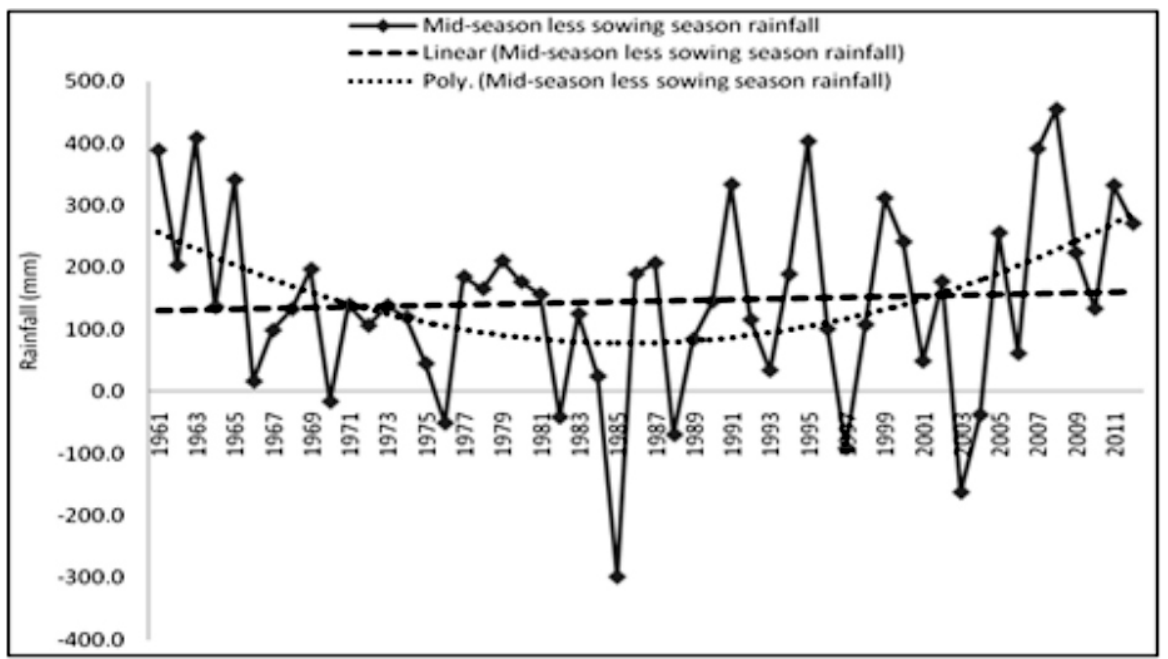

Fig. 3b: Annual trend of mid-season rainfall less sowing season rainfall in Ondo

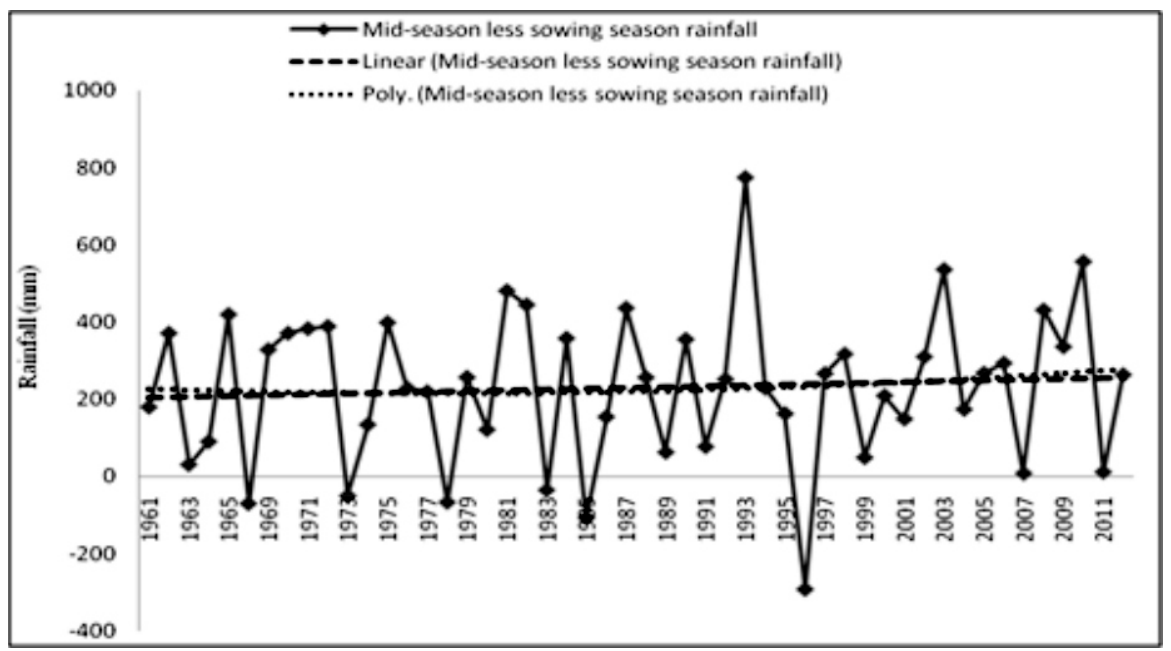

Fig. 3c: Annual trend of mid-season rainfall less sowing season rainfall in Port Harcourt

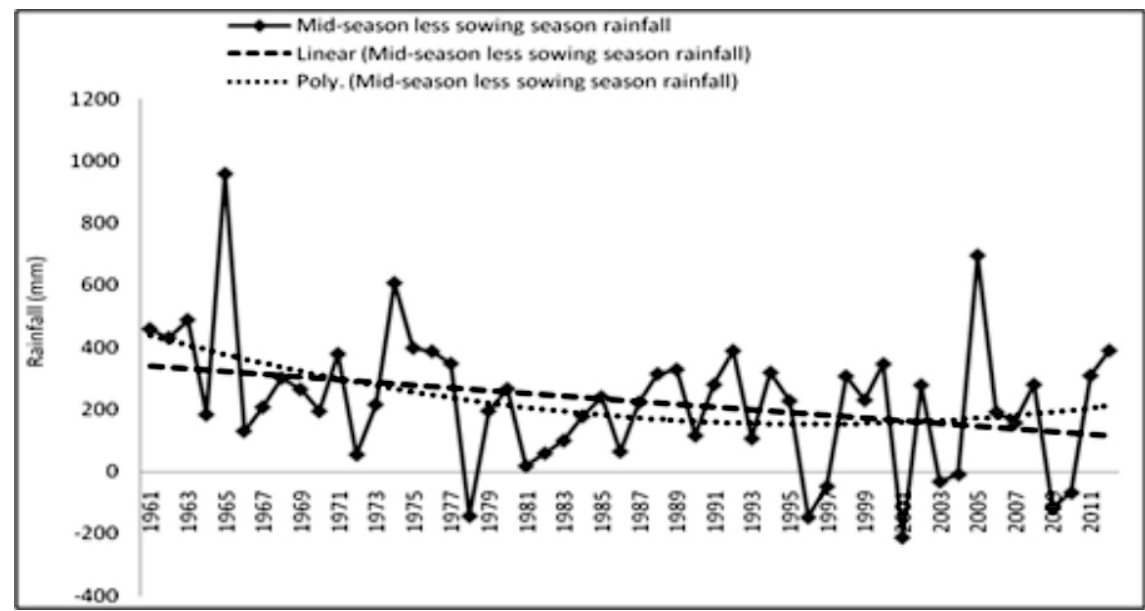

Fig. 3d: Annual trend of mid-season less sowing season rainfall in Benin \ 


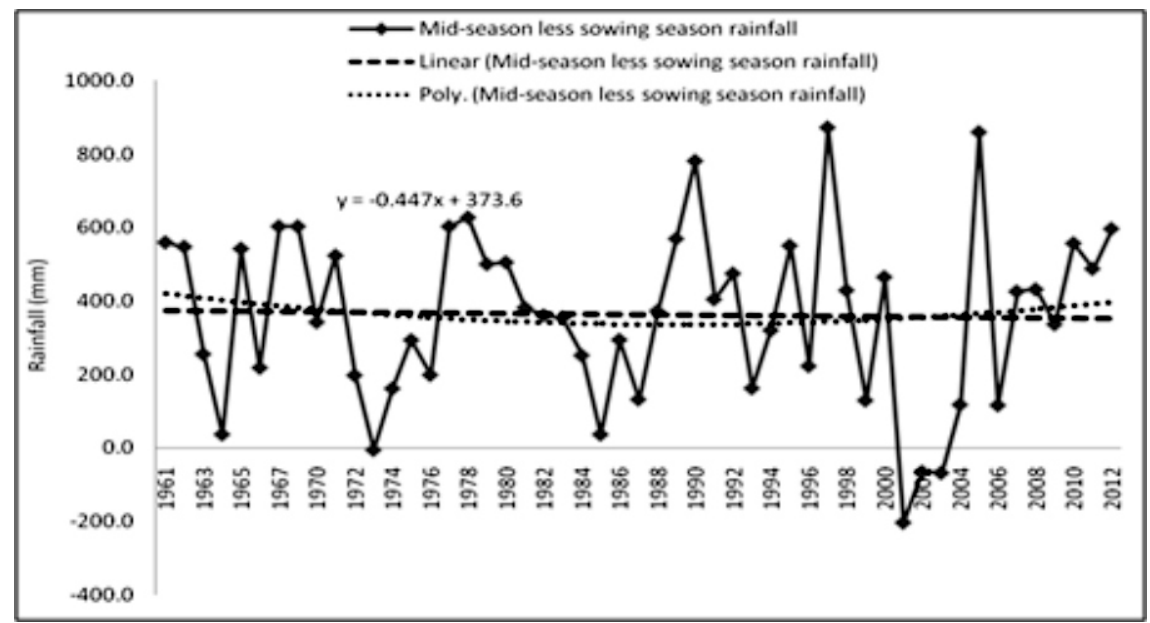

Fig. 3e: Annual trend of mid-season less sowing season rainfall in Calabar

The annual trends of sowing season and midseason rain-days are presented in Fig. 4 (a-e). All the stations witnessed downward linear annual trends of rain-days during the sowing and midseason. The trend was significantly downward in only Port Harcourt $(\mathrm{r}=-0.268, \mathrm{P}<0.05)$ during the sowing season, while during the mid-season, significant downward trend was observed in Warri $(\mathrm{r}=-0.301, \mathrm{P}<0.05)$ and Ondo $(\mathrm{r}=-0.366, \mathrm{P}<$ 0.01). The second order polynomials of the trends of sowing season and mid-season rain-days indicated slight tendencies toward recovery in all the stations, especially beyond year 2000 with the exceptions of Port Harcourt with declining tendency after increasing trend during the midseason of rice farming calendar.

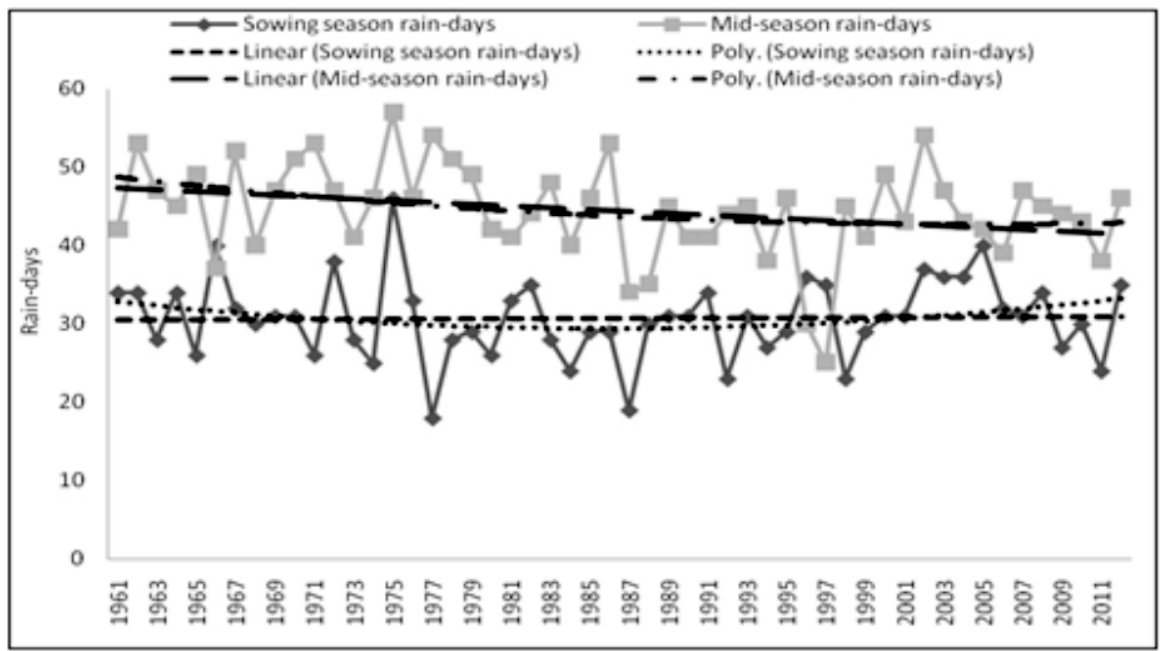

Fig. 4a: Annual trends of sowing season and mid-season rain-days in Warri 


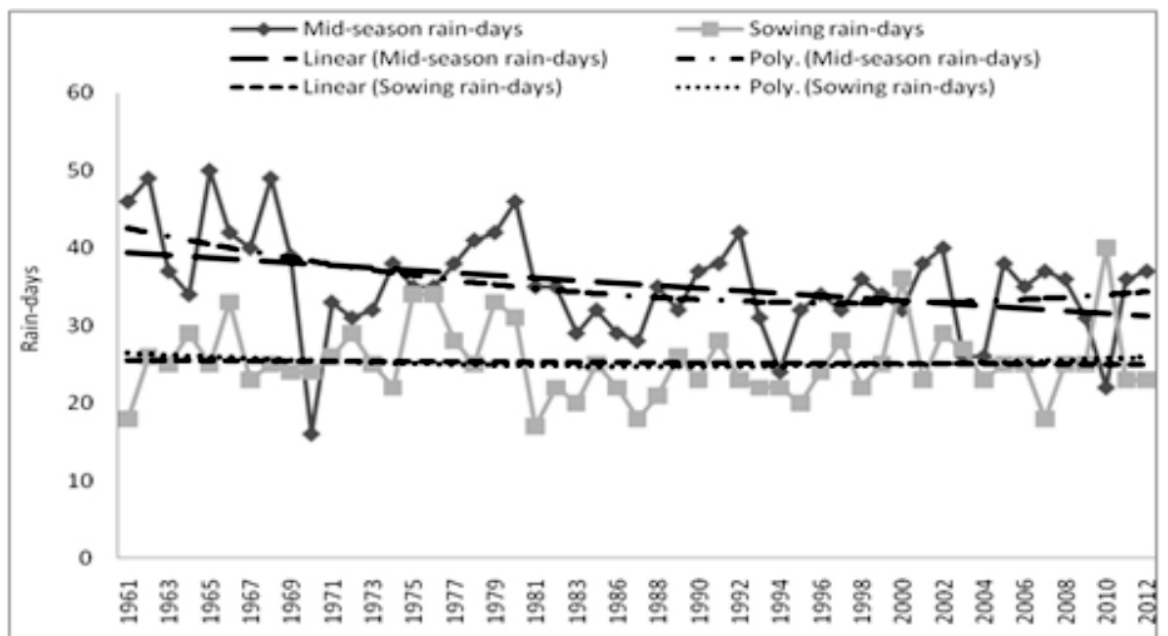

Fig. 4b: Annual trends of sowing season and mid-season rain-days in Ondo

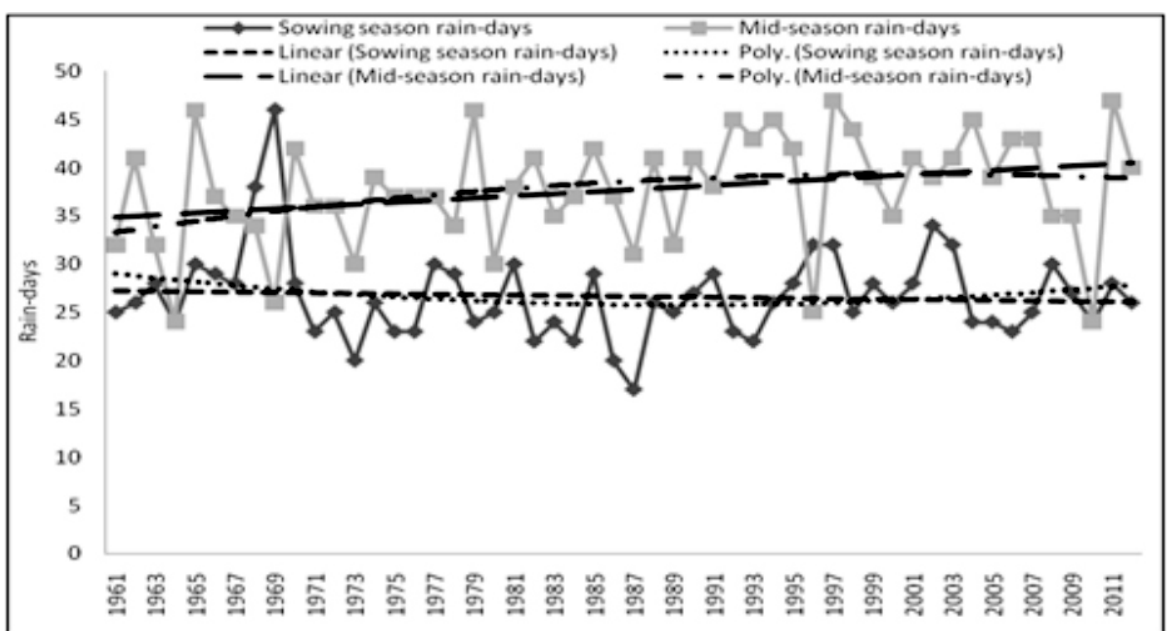

Fig. 4c: Annual trends of sowing season and mid-season rain-days in Port Harcourt

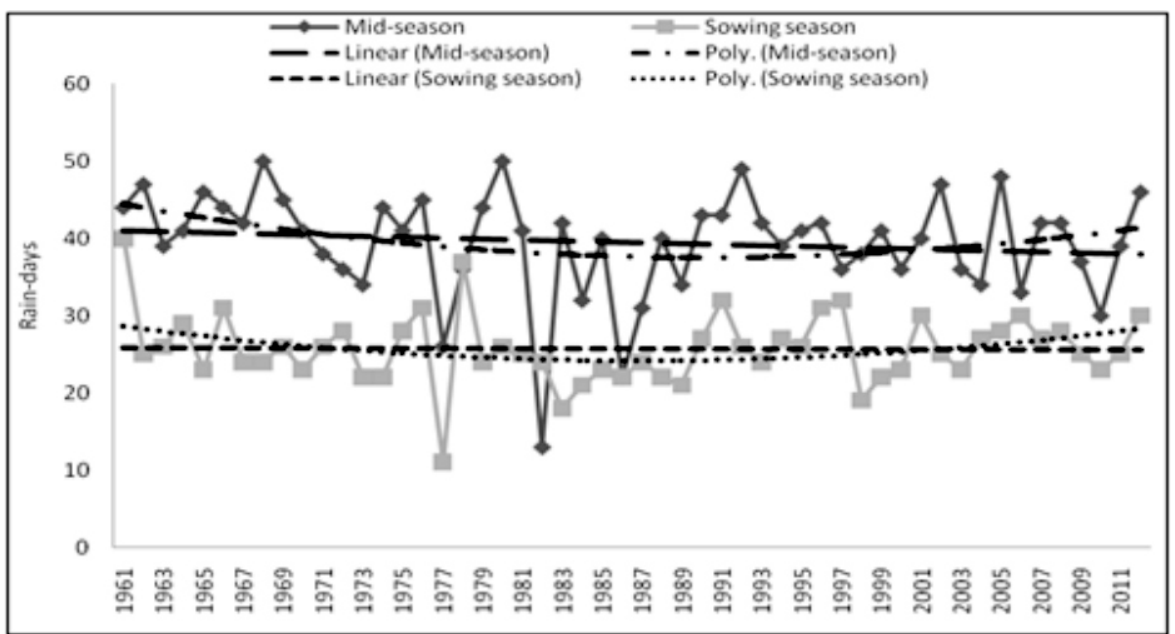

Fig. 4d: Annual trends of sowing and mid-season rain-days in Benin 


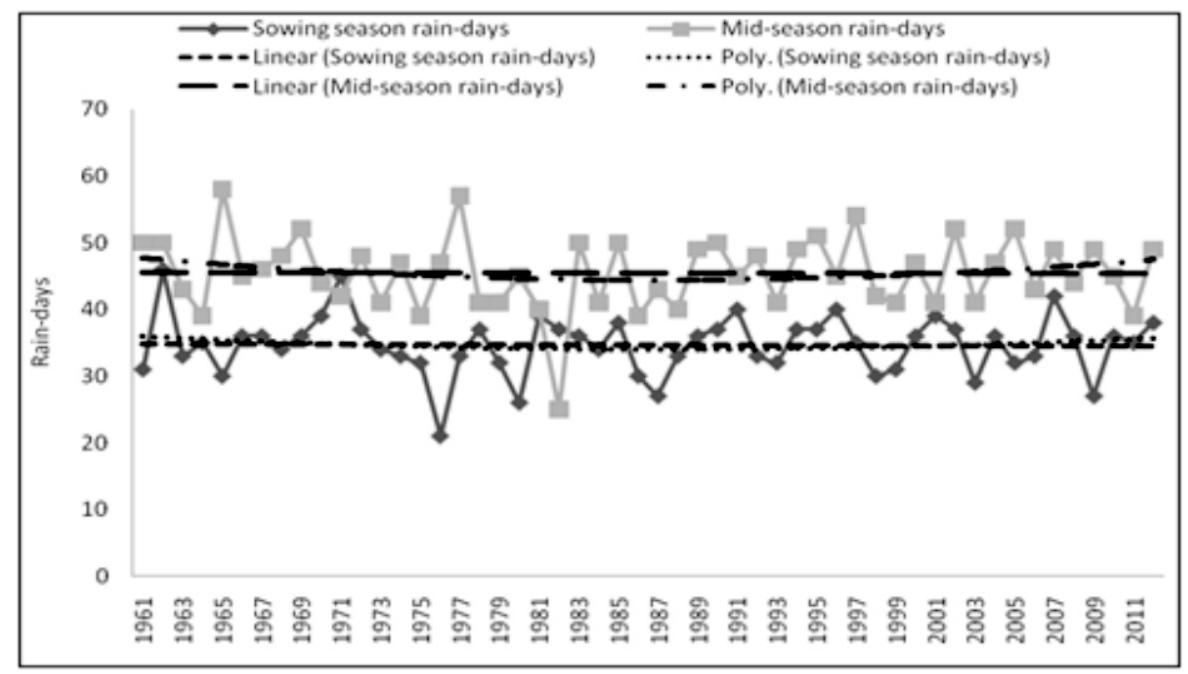

Fig. 4e: Annual trends of sowing season and mid-season rain-days in Calabar

The linear trends of mid-season less sowing season rain-days are presented in Fig. 5 (a-e). While Warri, Ondo, Port Harcourt and Calabar witnessed upward linear trends annual rates of $0.402 \mathrm{~mm}, 0.661 \mathrm{~mm}, 1.432 \mathrm{~mm}$ and $0.777 \mathrm{~mm}$, Benin experienced downward trend at an annual rate of $-2.896 \mathrm{~mm}$. While the second order polynomial showed declining trends after increase in Warri and Port Harcourt, Ondo, Benin and Calabar revealed recovery tendencies after the period of decline. Difference in the trends of midseason less sowing season rain-days were, however, not significant in all the stations. After established rainfall in the months of May and June which coincide with the season of planting and germination of rice in the region, sustained rainfall is germane to the healthy growth and yield of rice. Since rainfall is usually higher during the mid-season (July-August) and even up to September when the ITD has attained its northernmost excursion (Ojo, 1977; Olaniran, 2002; Umar, 2010), the declining annual trends of sowing season less mid-season rain-days might imply crop-moisture deficiency and need for irrigation.

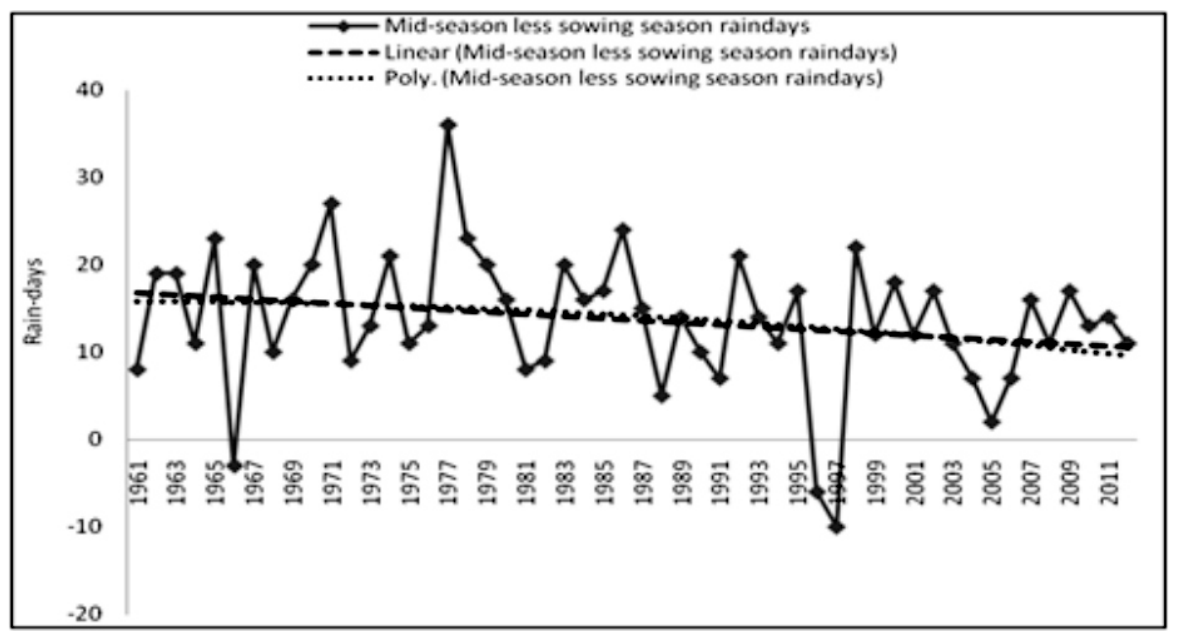

Fig. 5a: Annual trends of mid-season less sowing season rain-days in Warri 


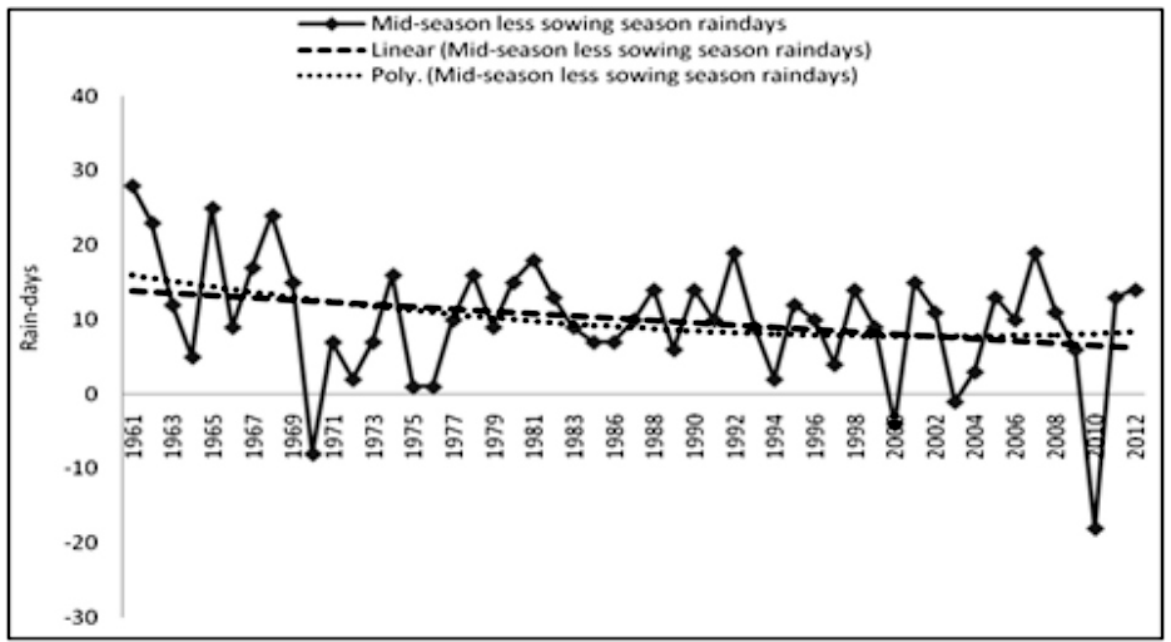

Fig. 5b: Annual trends of mid-season less sowing season rain-days in Ondo

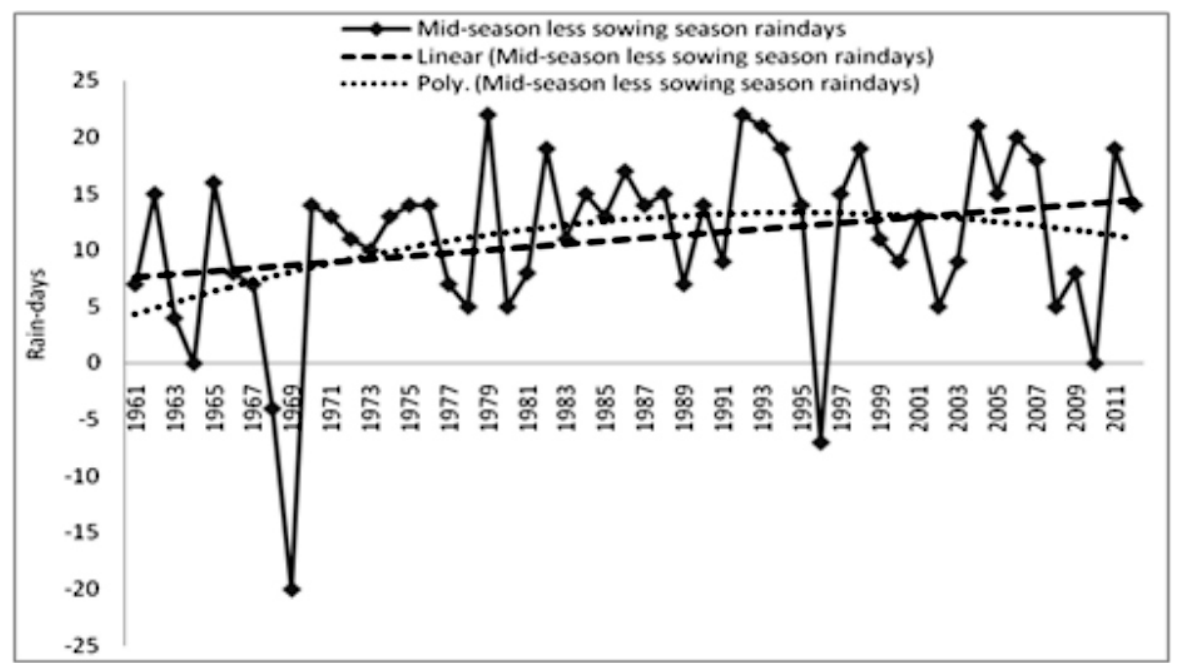

Fig. 5c: Annual trends of mid-season less sowing season rain-days in Port Harcourt

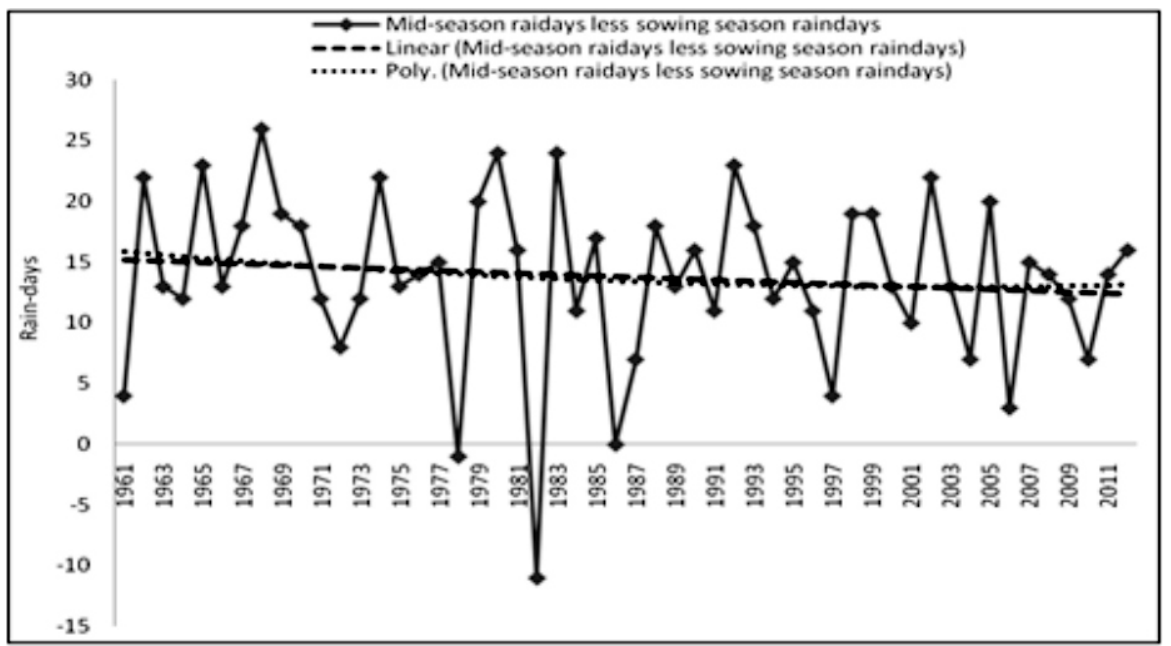

Fig. 5d: Annual trends of mid-season less sowing season rain-days in Benin 


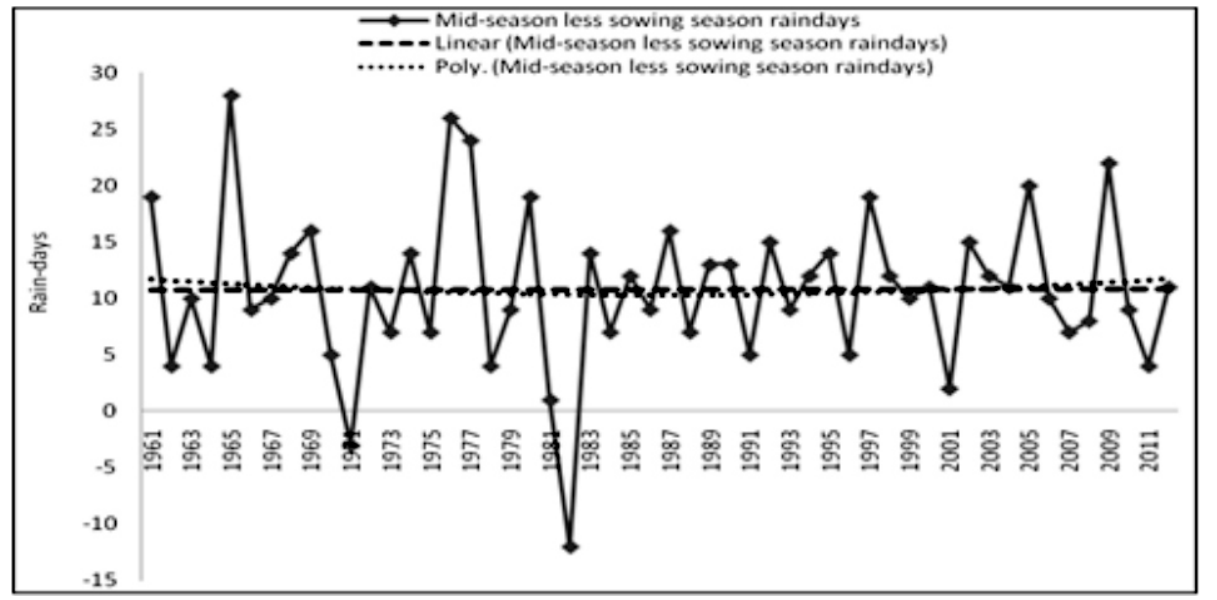

Fig. 5e: Annual trends of mid-season less sowing season rain-days in Calabar

The change in the mean sowing season rainfall and mean mid-season rainfall in the selected synoptic weather stations between the periods of climatological normal (1961-1990) and postclimatological (1991-2012) are presented in Fig. 6. During the sowing season, annual rainfall during the period of post-climalotological normal (19912012) exceeded that of the period of climatological normal (1961-2012) in Warri, Port
Harcourt, Benin and Calabar while Ondo witnessed decrease in rainfall during the period of post-climatological normal. Mean mid-season rainfall was higher during the post-climatological normal compared to the period of climatological normal in all the synoptic weather stations. The lower mean rainfall experienced in Ondo during the sowing season was a clear signal of the need for irrigation for adequate and timely cropmoisture availability.

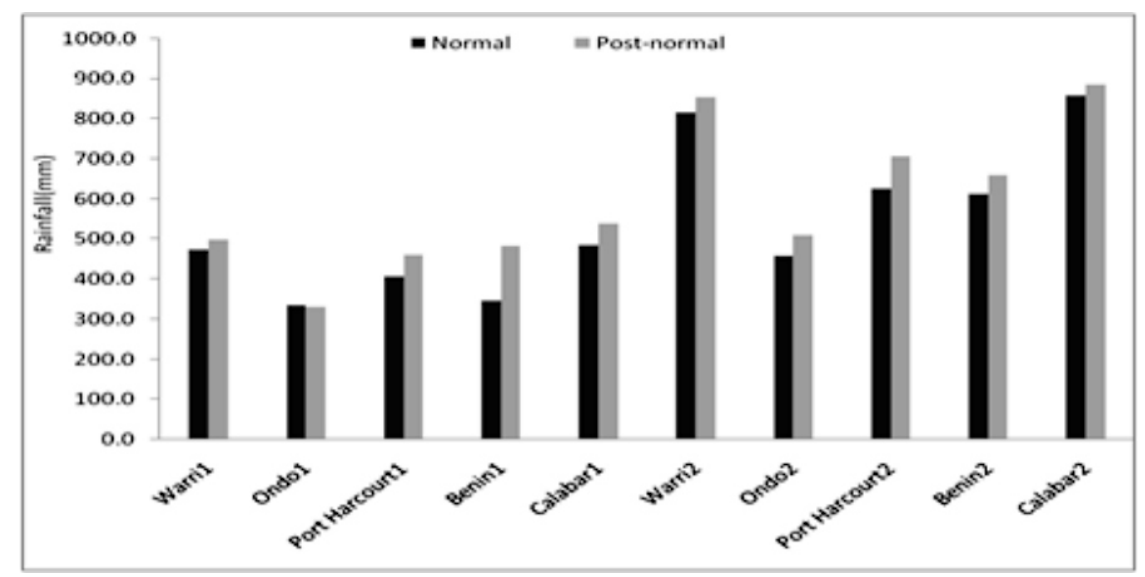

Fig. 6: Change in sowing and mid-season rainfall between the periods of climatological normal (1) and post climatological normal (2)

Fig. 7 shows the changes in mean sowing season and mean mid-season rain-days between the period of climatological normal (1961-1990) and post-climatological normal (1991-2012) in the selected synoptic weather stations. The change in mean rain-days during the sowing season appears to be similar to that of sowing season rainfall with Warri, Port Harcourt, Benin and Calabar witnessed higher rain-days during the period of post-climatological normal while Ondo recorded less rain-days during the same period. However, while in Port Harcourt, Benin and Calabar, mean mid-season rain-days were higher during the period of post-climatological normal, Warri and Ondo witnessed mid-season rain-days during the period of post-climatological normal. The lower mean rain-days in Warri and Ondo during the period of post-climatological normal could be adverse to the growth and yield of rice. 


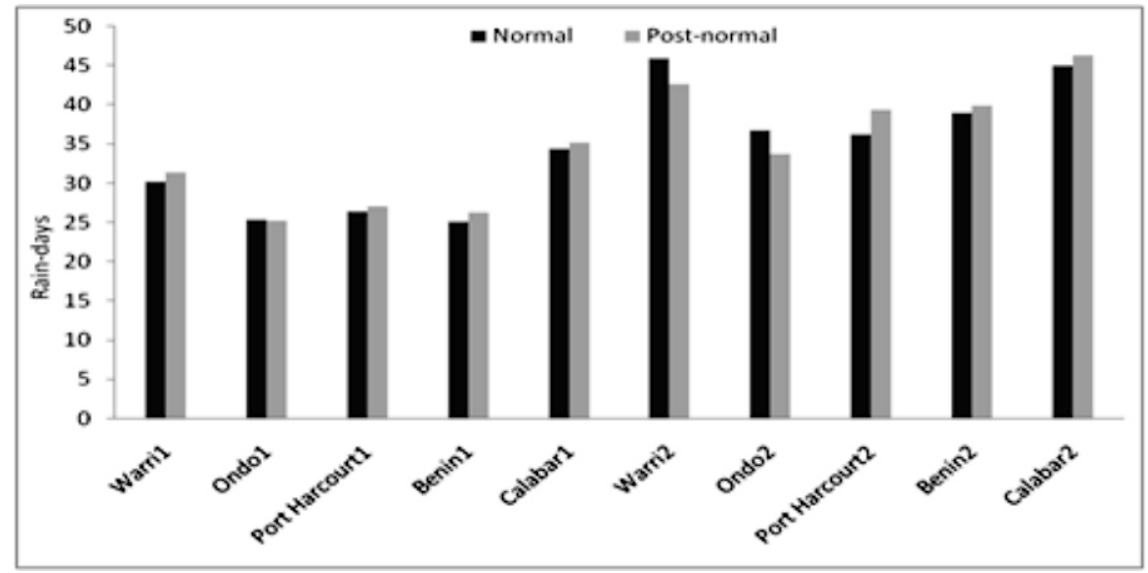

Fig. 7: Change in sowing and mid-seasons rain-days between periods of climatological normal (1) and post-climatological normal (2)

The intensities of droughts in the selected stations are presented in Table 2 . The drought incidences were predominantly of slight and moderate intensities during the sowing and mid-season with the sowing season having higher prevalence. The frequencies of drought of slight intensities in Warri, Ondo, Port Harcourt, Benin and Calabar during the sowing season were 20, 23, 34, 20 and 18 respectively. On the other hand, the aggregates of droughts of moderate intensities in Warri, Ondo, Port Harcourt, Benin and Calabar were 18, 19, 18, 20 and 4 respectively. Apart from the incidence of droughts of slight and moderate intensities, Port Harcourt and Benin were worst hit in terms of the prevalence of droughts of severe and disastrous intensities with each of the two stations having 4 incidences each during the period under consideration. Irrespective of intensities, from the analysis, it is clear that Port Harcourt was plagued with the highest incidence of droughts while Calabar was least affected. The relatively low incidence of droughts in Calabar during the sowing season and mid-season confirms the increasing trend of annual rainfall, particularly in the coastal south-eastern parts of Nigeria where Calabar is located (Olaniran, 2002). The incidences of droughts, especially during the sowing season which were characterized with erratic onset of the wet season (Atedhor, 2016) and particularly in Port Harcourt and Benin, also suggested the need for irrigation as alternative and/or a complementary source of soil moisture which is vital to crops growth and yield. According to Onu et al. (2015), drought could therefore be considered as one of the non-price factors that affect local rice production in Nigeria and should be given priority attention in the short and longterm in order to attain self-sufficiency. Besides, the period of drought is often characterised with dryness and high temperatures. Yet increase in temperature beyond optimum level for rice production lead to decrease in yield (Nyang'au et al., 2014). 


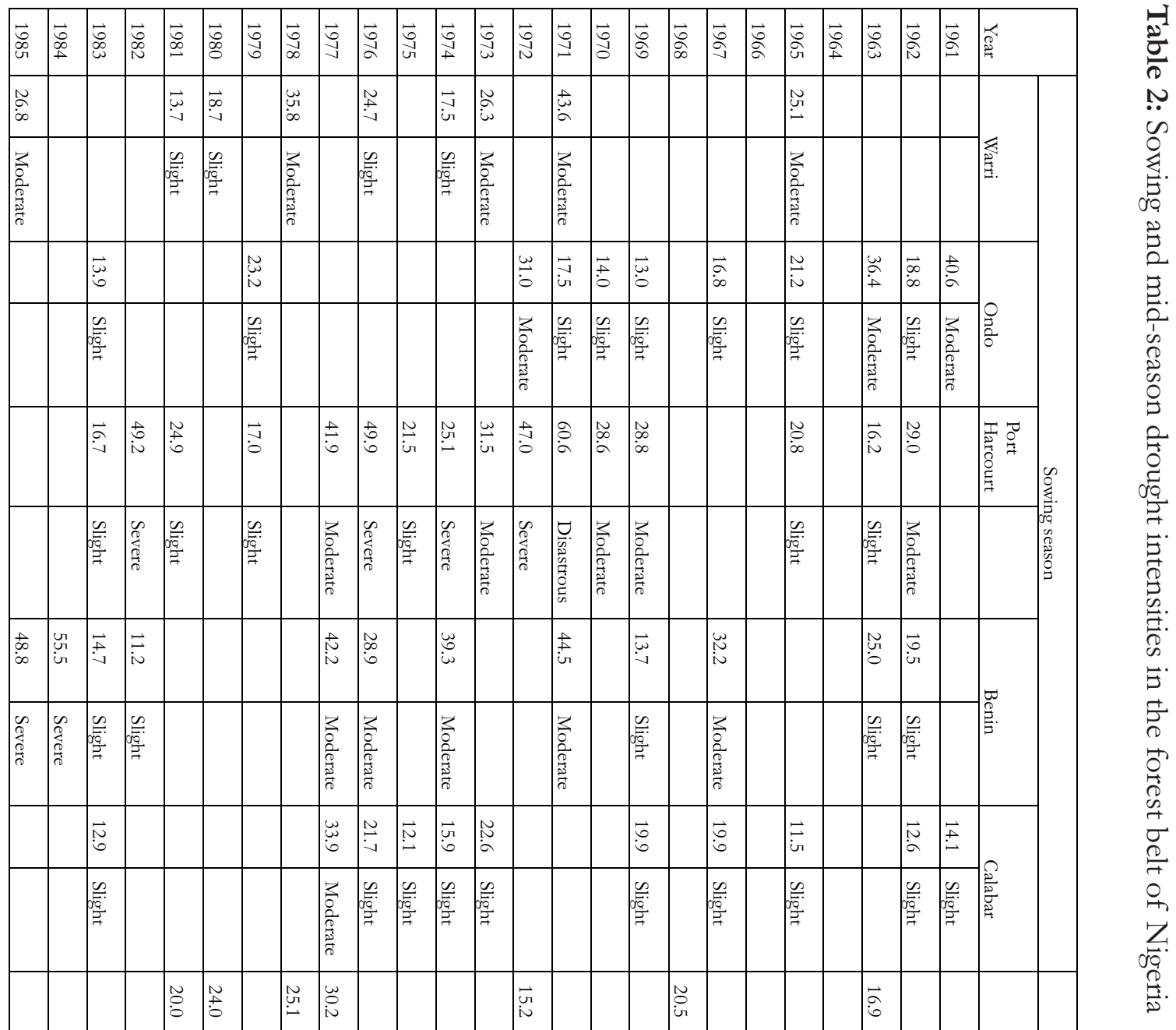




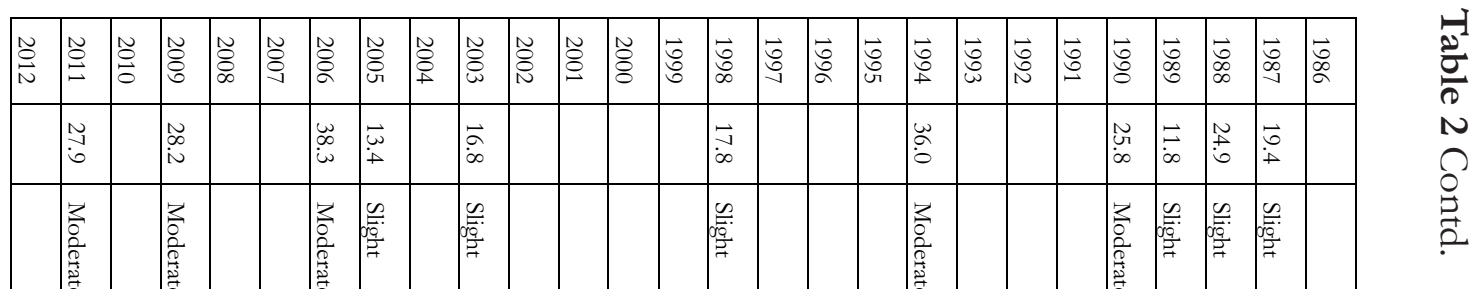

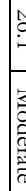

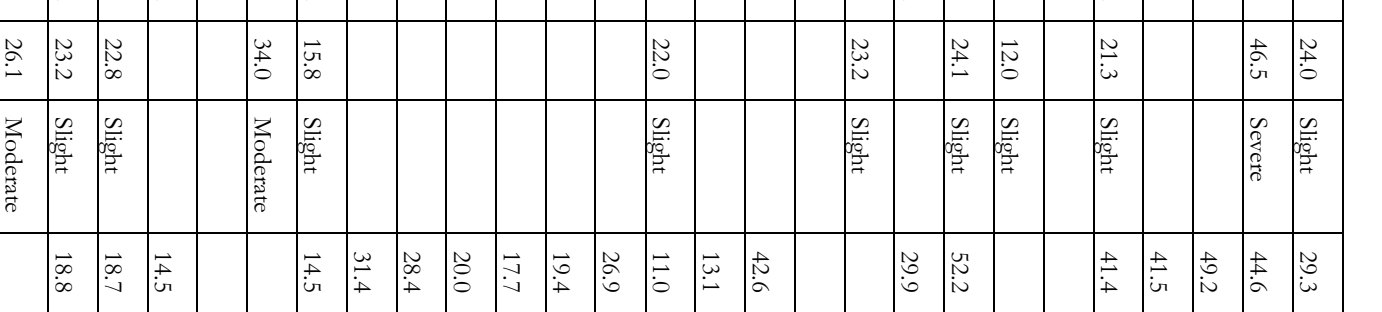

\begin{tabular}{|c|c|c|c|c|c|c|c|c|c|c|c|c|c|c|c|c|c|c|}
\hline 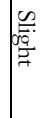 & 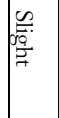 & 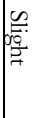 & 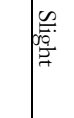 & 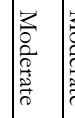 & 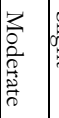 & 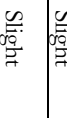 & 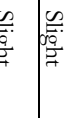 & 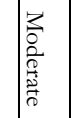 & 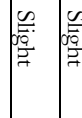 & 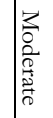 & & 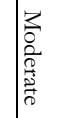 & 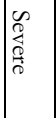 & & 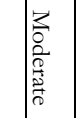 & 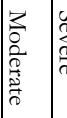 & & \\
\hline & & & & $\underset{i}{+}$ & & & & & $\mid$\begin{tabular}{c|c}
$\tilde{c}$ \\
$\dot{\omega}$ \\
$\dot{\omega}$
\end{tabular} & & & & $\underset{N}{N}$ & & & 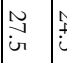 & $\begin{array}{l}n \\
c \\
c\end{array}$ & 湈 \\
\hline & & & & 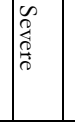 & & & & & 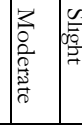 & & & & 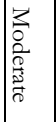 & & & 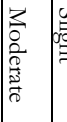 & $\frac{n}{2}$ & \\
\hline & $\mid \begin{array}{c}\vec{j} \\
\infty\end{array}$ & & & & & & & $\stackrel{N}{+}$ & 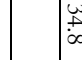 & & & & $\mid \begin{array}{l}N \\
N \\
\infty \\
\infty\end{array}$ & 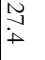 & $\mathbb{N}_{\mathrm{N}}$ & & & \\
\hline & 紫: & & & & & & & 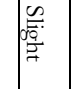 & & & & & 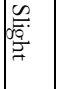 & 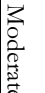 & 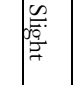 & & & \\
\hline & 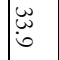 & $\stackrel{\infty}{-\infty}$ & $\stackrel{n}{\pi}$ & & & & 是 & 岕 & & 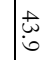 & $\mid \begin{array}{l}\mathbb{u} \\
\dot{\infty}\end{array}$ & & 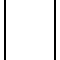 & 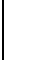 & & & b & \\
\hline & 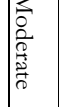 & 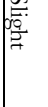 & 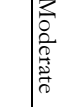 & & & & 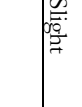 & 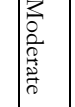 & & 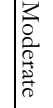 & 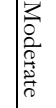 & & 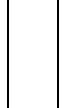 & & & & 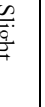 & \\
\hline & $\mid \begin{array}{l}\vec{\infty} \\
i \\
i\end{array}$ & & 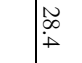 & & 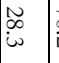 & ì & & & & $\mid \begin{array}{l}N \\
i\end{array}$ & & & 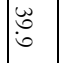 & $\stackrel{F}{\stackrel{f}{f}}$ & $\stackrel{F}{ \pm}$ & & 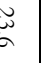 & $\overrightarrow{6}$ \\
\hline & 紫: & & 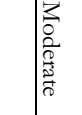 & & 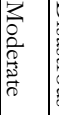 & & & & & 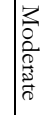 & & & 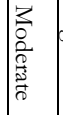 & $\mid$ & 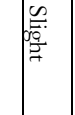 & & $\frac{5}{2}$ & 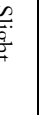 \\
\hline 岕 & & & & & $\vec{u}$ & & $\overrightarrow{\overrightarrow{0}}$ & & $i_{i}^{N}$ & 芯 & 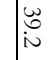 & & 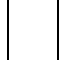 & & & 芯 & $\begin{array}{l}6 \\
\infty \\
\infty\end{array}$ & $E$ \\
\hline 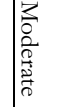 & & & & & 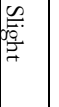 & & 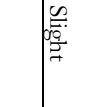 & & 告 & 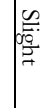 & 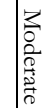 & & $t$ & & & 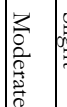 & 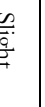 & \\
\hline & $\mid \begin{array}{l}\overrightarrow{ \pm} \\
\stackrel{ \pm}{v}\end{array}$ & 志 & & & & $\underset{\mathrm{N}}{\mathbb{N}}$ & & & $\vec{\infty}$ & $\underset{N}{N}$ & ب̂ & & $\mathscr{\omega}_{\sigma}$ & & & & & ك. \\
\hline & 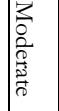 & & & & & 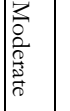 & & & $\frac{5}{\sqrt{50}}$ & 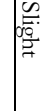 & 紫 & & 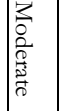 & & 变 & & & \\
\hline & & & & & & $\mid \begin{array}{l}\infty \\
\substack{\infty \\
\infty}\end{array}$ & & & & & & & ज̆ & & & & & \\
\hline & & & & & & 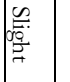 & & & & & & & 䇾哭 & & & & & \\
\hline
\end{tabular}




\section{CONCLUSION}

The study examined the annual trends of rainfall during the sowing season and mid-season as well as drought intensities in the forest belt of Nigeria using five selected synoptic weather stations (Warri, Ondo, Port Harcourt, Benin and Calabar). The rainfall and rain-days data covered the period 1961 to 2012. The study revealed that while rainfall during the growing season experienced upward trends in Ondo, Port Harcourt, Benin and Calabar, with statistical significance in Benin and Calabar, Warri witnessed insignificant decline. In the mid-season, rainfall increased insignificantly in Warri, Ondo, Port Harcourt and Calabar but declined insignificantly in Benin. All the stations recorded decline in rain-days during the sowing season with only Port Harcourt exhibiting statistical significance while downward trend during the mid-season showed statistical significance in Warri and Ondo. Rainfall was higher in the period of post-climatological normal compared to the period of climatological normal in all the stations with the exception of Ondo which experienced higher rainfall during the period of climatological normal. Rain-days were higher in the era of post-climatological normal compared to the period of climatological normal in all the stations with the exception of Ondo and Warri which recorded higher number of rain-days during the period of climatological normal. The drought intensities revealed spatial and temporal variations among the stations and were mainly of slight and moderate categories during the two seasons with pockets of severe and disastrous intensities in Port Harcourt and Warri. It is therefore concluded that rainfall witnessed upward trends in all the stations with the exception of Warri and Benin which experienced decline during the sowing season and mid-season respectively, while rain-days decreased during the two seasons in the stations coupled with the droughts of primarily slight and moderate intensities. Rice production during 2000-2012 period witnessed upward trend amid inter-annual fluctuation, especially from 2006 to 2012. Rainfall forecast and timely irrigation for optimal rice production are suggested for the region.

\section{ACKNOWLEDGEMENT}

The authors appreciate the Nigerian Meteorological Agency for the rainfall and rain- days data used in this study

\section{REFERENCES}

Abeysingha, N. S., Singh, M., Islam, A., \& Sehgal, V. K. 2016. Climate change impacts on irrigated rice and wheat production in Gomti River basin of India: a case study. SpringerPlus, 5: 1250 (DOI 10.1186 /s40064-016-2905-y)

ACPC (Economic Commission for Africa) 2011. Climate change and Agriculture: Analysis of Knowledge Gaps and Needs, United Nations economic Commission for Africa, Working Paper 7

Adebayo, W. O. 1999. Spatio-temporal dynamics of temperature and rainfall fluctuations in Nigeria. Unpublished Ph.D Thesis Submitted to the Department of Geography, University of Ibadan, Ibadan

Ara, I., Lewis, M., \& Ostendorf, B. 2016. Spatio-temporal analysis of the impact of climate, cropping intensity and means of irrigation: an assessment on rice yield determinants in Bangladesh. Agriculture \& Food Security 5: 12 (DOI 10.1186/s40066016-0061-9)

Atedhor, G. O. 2016. Planting season's rainfall trends and droughts in the forest belt of Nigeria, Ghana Journal of Geograpby 8 (2): 43-58

Ati, O. F., Iguisi, E. O. and Mohammed, S. O. 2010. Effects of El Nino/southern oscillation (ENSO) on rainfall characteristics in Katsina, Nigeria, Journal of Agricultural Research 5 (23): 3273-3278

Ayinde, O. E., Ojehomon, V.E. T., Daramola, F. S. and Falaki, A.A. 2013. Evaluation of the effects of climate change on rice production in Niger State, Nigeria. Ethiopian Journal of Environmental Studies and Management 6: 763-773

Ayoade, J. O. 2002. Introduction to Agroclimatology. Vintage Publisher, Ibadan

Ayoola, J. B., Dangbegnon, C., Daudu, C. K., Mando, A., Kudi, T. M., Amapu, I. Y., Adeosun, J. O. and Ezui, K. S. 2011. Socioeconomic factors influencing rice production among male and female farmers in northern guinea savanna Nigeria: lessons for promoting gender equity in action research, Agricultural and 
Biology Journal of North America 2 (6): 1010 1014.

Craufurd, P. Q. \& Wheeler, T. R. 2009. Climate change and the flowering time of annual crops. Journal of Experimental Botany $60(9): 2529-2539$ (doi:10.1093 /jxb/erp196)

Crop Calendar of Nigeria (n.d.) Available at: peaceworkspartners.org/vault/Nigeria/ Research/Nigeria Statistics/crop_calender_nigeria.pdf

Gornal, J. Betts, R., Burke, R., Clark, R., Camp, J., Willett, K., \& Wilshire, A. 2010. Implications of climate change for agricultural productivity in the early twenty-first century. Philosophical Transactions of the Royal Society B 365: 2973 2989 (doi:10.1098/rstb.2010.0158)

Ilesanmi, O. O. 1971. An empirical formulation of an ITD rainfall model for the tropics: A case study of Nigeria, Journal of Applied Meteorology 10: 882-891

Kang, Y., Khan, S. \& Ma, X. 2009. Climate change impacts on crop yield, crop water productivity and food security - A review. Progress in Natural Science 19: 1665-1674 (doi:10.1016/j.pnsc.2009.08.001)

Kihoro, J., Bosco, N. J. \& Murage, H. 2013. Suitability analysis for rice growing sites using a multicriteria evaluation and GIS approach in great Mwea region, Kenya. SpringerPlus, 2: 265 (doi:10.1186/21931801-2-265)

Koide, N., Robertson, A. W., Ines, A. V. M., Qian, J., DeWith, D. G., \& Lucero, A. 2013. Prediction of rice production in the Philippines using seasonal climate forecasts. Journal of Applied Meteorology \& Climatology 52: 552-569 (DOI: 10.1175/JAMC-D-11-0254.1)

Lobell, D. B. and Asseng, S. 2017. Comparing impacts of climate change based on process-based and statistical crop models. Environmental Research Letters 12: 015001 (doi:10.1088/1748-9326/015001)

Nyang'au, W. O., Mati, B. M., Kalamwa, K. Wanjogu, R. K. \& Kiplagat, L. K. 2014. Estimating rice yield under changing weather conditions in Kenya using CERES Rice Model. International Journal of Agronomy, 2014, Article ID 849496, (http:/ /dx.doi.org/10.1155/2014/84949 6)

Odekunle, T. O. 2004. Rainfall and length of the growing season in Nigeria. International Journal of Climatology 24: 467- 479

Odekunle, T. O. 2009. An Assessment of the influence of the inter-tropical discontinuity on inter-annual rainfall characteristics in Nigeria. Geographical Research 48 (3): 314-326, (doi: 10.1111/j.1745-5871.2009.00635.x)

Ojo, O. 1977. The climate of West Africa, Hienemann, London

Olaniran, O. J. 2002. Rainfall anomalies: the contemporary understanding, 55th Inaugural Lecture Series, University of Ilorin, Ilorin, Nigeria

Onu, D. O., Obike, K. C., Ebe, F. E. and Okpara, B. O. 2015. Empirical assessment of the trend in rice production and imports in Nigeria (1980-2013). International Research Journal of Agricultural Science and Soil Science 5 (6): $150-158$, ( D O I : http:/dx.doi.org/10.14303/irjas.2015.07 5)

Ray, D. K., Gerber, J. S., MacDonald, G. K. \& West, P. C. 2015. Climate variation explains a third of global crop yield variability. Nature Communication, 6:5989 (DOI: 10.1038/ncomms6989)

Redfern, S. K., Azzu, N. \& Binamira, J. S. (n.d.) Rice in southeast Asia: facing risks and vulnerabilities to respond to climate change. 295-314

Sultan, B., Guan, K., Kouressy, M., Biasutti, M., Piani, C., Hammer, G. L., McLean, G. and Lobell, D. B. 2014. Robust features of future climate change impacts on sorghum yields in West Africa. Environmental Research Letters 9: 104006. (doi:10.1088/1748-9326/9/10/104006)

Umar, A. T. 2010. Recent trends and variability in the length of the growing season in Northern Nigeria. Journal of Meteorology and Climatological Science 8 (1): 40-52

Umar, A. T. 2012. Spatio-Temporal pattern of rainfall anomalies and its implications for crop production in Nigeria. In Odjugo, P. A. O., Asikhia, M. O. and Ikelegbe, O. O. (eds.) climate change and variability: saving our tomorrow today, Proceedings 
of the 2012 Annual Conference of Nigerian Meteorological Society, 68-72

Wart, J. V., Grassini, P. and Cassman, G. C. 2013. Impact of derived global weather data on simulated crop yields. Global Change Biology
19:3822-3832, (doi: 10.1111/gcb.12302) Zhao, X. \& Fitzgerald, M. 2013. Climate Change: Implications for the yield of edible rice. PLOS One 8 (6): e66218 